\title{
Keutuhan Pernikahan Kristen Dalam Matius 19:6 Dan Implikasinya Terhadap Perceraian Dan Pernikahan Kembali Dalam Rumah Tangga Kristen Masa Kini
}

\author{
Pasko Tambun, ${ }^{1} *$ Mangiringtua Togatorop, ${ }^{2}$ Rita Evimalinda ${ }^{3}$ \\ Prodi Studi Teologi, STT Real Batam \\ Prodi Studi Teologi, STT Real Batam \\ Prodi Studi PAK, STT Real Batam \\ tambunpasko@gmail.com
}

\begin{abstract}
Talking about divorce and remarriage then we will certainly be faced with a variety of different views and attitudes. One of the parties said that remarriage may be done if it is not compatible with each other, instead of causing fights and serious disputes, it is permissible to divorce. On the other hand remarriage can also be done if with a partner who was previously unable to provide compensation from the results of the marriage, so divorce and remarriage are legal matters. The Bible clearly states in Matthew 5: 32,19: 9; Mk 10:11-12; Luke 16:18 states that the actions of a man who divorces his wife alone causes the woman to commit adultery and who marries the woman who is divorced. commit adultery. Second, the act of divorcing his wife and marrying another woman he has lived in adultery and vice versa if a woman deliberately divorces her husband and marries another man, he has actually committed adultery. Third, the act of divorcing his wife and marrying another woman, he commits adultery and vice versa.
\end{abstract}

Keywords: Christian Marriage; Divorce; Wedding; Christian home

\begin{abstract}
Abstrak
Berbicara tentang perceraian dan pernikahan kembali maka kita pasti akan diperhadapkan dengan berbagai pandangan dan sikap yang berbeda. Salah satu pihak mengatakan bahwa pernikahan kembali boleh dilakukan apabila sudah tidak saling cocok satu dengan yang lain, daripada menimbulkan pertengkaran dan perselisihan yang berat maka diperkenankan untuk melakukan perceraian. Dipihak lain pernikahan kembali juga boleh dilakukan apabila dengan pasangannya yang dahulu tidak mampu untuk memberikan keterunan dari hasil pernikahan tersebut, sehingga bercerai dan menikah kembali adalah hal yang sah-sah saja. Alkitab dengan jelas menuliskan dalam Matius 5:32,19:9;Mrk 10:11-12;Lukas 16:18 menyatakan bahwa, perbuatan laki-laki yang menceraikan istrinya saja sudah mengakibatkan si wanita berzinah dan siapa yang menikah dengan wanita yang dicearaikan ia berbuat zinah. Kedua, perbuatan menceraikan istri dan menikah dengan wanita lain ia sudah hidup dalam perzinahan dan begitu juga dengan sebaliknya apabila wanita dengan sengaja menceraikan suaminya dan kawin dengan laki-laki lain,ia sesungguhnya sudah berbuat zinah. Ketiga, perbuatan menceraikan istri dan menikah dengan perempuan lain, ia berbuat zinah dan begitu juga dengan sebaliknya.

Keywords: Pernikahan Kristen; Perceraian; Pernikahan; Rumah Tangga Kristen
\end{abstract}

\section{PENDAHULUAN}

Perceraian dan Pernikahan Kembali sudah menjadi dua isu yang saat ini tidak lagi dapat dipisahkan dari kehidupan orang Kristen, karena peristiwa ini sudah banyak terjadi dan dilakukan oleh orang-orang Kristen. Disamping itu perdebatan tentang perceraian dan 
pernikahan kembali juga terus menimbulkan perbedaan pandangan di dalam gereja atau denominasi yang berkaitan dengan perdebatan biblika, pastoral, teologi dan etika. Pernikahan merupakan sebuah kondisi yang sangat penting dalam kehidupan umat beragama, tidak terkecuali agama Kristen. Namun seringkali kita melihat bahwa pernikahan kristen itu juga mengalami banyak persoalan ditengah-tengah umat Tuhan. Disatu sisi Tuhan tidak menghendaki perceraian, tetapi disisi lain manusia yang Dia ciptakan itu justru melakukannya. Hal ini senada dengan penjelasan Fredy Simanjuntak, Problematika serta tantangan keluarga pasca-modern adalah menemukan keseimbangan hubungan dalam kehidupan orang dewasa dan kehidupan anak-anak mereka dan untuk menemukan nilai-nilai yang konsisten yang dapat diperkuat dalam komunitas yang penuh kasih. ${ }^{1}$ Lebih lanjut lagi Fransiskus Irwan Widjaja mengatakan, problem atau konflik dalam keluarga merupakan bagian dari hidup manusia, yang tidak pernah terlepas dari kehidupan sehari-hari sehingga konflik perlu penanganan dan dicarikan solusinya. ${ }^{2}$ Oleh karena itu perlu keseimbangan di dalam keluarga seperti yang Otieli Harefa jelaskan, bahwa keluarga sebagai komunitas bersama dan keluarga tidak dapat dimonopoli oleh suatu elemen saja tetapi menjadi saranan bagi semua anggota untuk belajar dan bertumbuh secara social dan rohani. $^{3}$

Penulis berpendapat bahwa Perceraian dan Pernikahan kembali sebenarnya sudah sarat dengan berbagai persoalan oleh karena itu kita akan membahasnya secara konrehensif untuk dapat menghasilkan suatu pandangan baru untuk menjadi pegangan dalam pembinaan-pembinaan keluarga Kristen.

\section{METODE}

Metode Penelitian yang akan digunakan oleh penulis adalah penelitian kualitatif, yaitu penelitian yang bersifat deskriftif analitik terhadap data yang dipaparkan berupa ungkapan-ungkapan kata, dokumen tertulis. Hal ini bertujuan untuk mendapatkan pemahaman yang benar atau kesesuaian antara antara pengetahuan dan realitas yang timbul ditengah-tengah umat.

\section{HASIL DAN PEMBAHASAN}

\section{Tafsiran Matius 19:6}

Matius menceritakan tujuan dari kehadiran Yesus adalah sebagai perwujudan dari rancangan Allah, yang mana kehebatannya tidak ditentukan oleh oleh kekuatan manusia tetapi hanya berdasarkan Anugerah Penyelamatan Kudus, yang tidak sama/berbeda dengan apa yang dilakukan oleh pemerintahan Romawi. Yesus memperkenalkan sebuah tatanan

\footnotetext{
${ }^{1}$ Fredy Simanjuntak, "Problematika Disorganisasi Dan Disharmonisasi Keluarga," in Keluarga Yang Misioner, 2018.

${ }^{2}$ Fransiskus Irwan Widjaja, "Manajemen Konflik Keluarga," in Keluarga Yang Misioner, 2018, 103-111.

${ }^{3}$ Otieli Harefa, "Keluarga Sebagai Pusat Pembentukan Rohani Anak," Real Didache 1, no. 1 (2016): 1-22.
} 
baru yang menghasilkan ketenangan/kenyamanan baru bagi setiap orang yang mendengar dan mau mengikutinya. ${ }^{4}$

Di dalam ayat ke enam ini penegasan tentang kesatuan antara laki-laki dan perempuan yang dipersatukan dalam sebuah ikatan, tiak boleh di putuskan oleh manusia. Istilah Yunani "mempersatukan" menggunakan kata $\sigma 0 v \varepsilon \zeta \varepsilon v \xi \varepsilon v$ (mengikat mereka dalam satu kuk) yang dalam Bahasa Indonesia diartikan "dipersatukan" istilah jangan dipisahkan

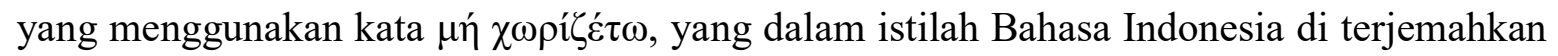
dengan tidak boleh diceraikan. ${ }^{6}$

Jadi apa yang telah diikat oleh Tuhan dalam hubungan sebuah pernikahan janganlah dipisahkan oleh seorang manusia dalam hal ini kata Yunani yang dipakai untuk manusia adalah kata $\alpha v \theta \rho \omega \pi$ ó yang berarti manusia dalam hal ini adalah laki-laki ${ }^{7}$ maka semakin terlihat kaitan yang sangat jelas bahwa Tuhan Yesus hendak mengingatkan para orang Farisi secara khusus dalam hal ini para laki-laki yang memiliki kebiasaan menceraikan istrinya.

Kehadiran Yesus di galilea adalah bagian dari proses memproklamirkan dirinya adalah merupakan sebuah Misi Agung bagi penyelamatan seluruh umat manusia. Di bawah dominasi pemerintahan Romawi Yesus datang untuk membawa perubahan baru yang sama sekali berbeda dengan cara pemerintahan Romawi yang lebih banyak menekankan tindakan ketidak adilan dan kekerasan lainnya. Yesus membawa harapan bagi mereka yang sedang mengalami penindasan dan penganiayaan. ${ }^{8}$ Kehadiran Yesus di Galilea merupakan masa awal bahwa akan berkahirnya masa-masa kegelapan hidup dan akan beralih kepada kehidupan yang penuh dengan Damai sejahtera (Mat 4:12-17) yang terjadi melalui kematian, kebangkitan yang dijalani oleh Tuhan Yesus. ${ }^{9}$

Kehidupan masyarakat dibawah otoritas pemerintahan romawi berjalan dalam lingkaran kemutlakan pengaruh dari kaisar sebagai lambang kehadiran dewa di tengahtengah masyarakat, sehingga masyrakat harus sungguh-sungguh patuh dan taat secara totalitas, apabila ada yang menunjukkan ketidaktaatan maka mereka pasti akan mendapatkan ganjaran hukuman yang cukup serius dari pihak kekaisaran dan orang-orang Kristen pada saat itu mendapat ancaman dan tekanan yang cukup berat.

Perikop ini adalah merupakan sebuah percakapan serius dari orang-orang farisi dengan Tuhan Yesus yang memperdebatkan tentang perceraian, dimana orang-orang Farisi berusaha meminta pandangan Tuhan Yesus tentang perceraian dengan mengutip ulangan 24:1-4. Perdebatan tentang perceraian memang sudah semenjak dahulu berkembang dan

\footnotetext{
${ }^{4}$ Warrant Carter, Mathew and Empire: Initial Exploration, n.d.

${ }^{5}$ Schafer dan Freshia Aprily Ross, Bercerai: Boleh Atau Tidak?: Tafsiran Terhadap Teks-Teks Perjanjian Baru (Jakarta: BPK Gunung Mulia, 2017).

${ }_{7}^{6}$ BGM Morph + Barclay - Newman, "Bible Work 6," n.d.

${ }^{7}$ Ibid.

${ }^{8}$ Sugirtharajah, A Post Colonial Commentary On The New Testament Writing, n.d.

${ }^{9}$ Mathew Gundry, A Commentary On His Handbook For A Mixed Church Under Persecution (Michigan Baker Akademik, 2010).
} 
sampai sekarang perdebatan ini terus muncul dan tidak kunjung selesai. Dalam Tafsiran Alkitab Masa kini dikatakan bahwa hal ini bukanlah hendak mengatakan bahwa ada aturan tentang perceraian tetapi adalah merupakan mengatur terhadap kebiasaan kaum semit. ${ }^{10}$

Dalam Matius 5:31, Tuhan Yesus mengutif apa yang disampaikan oleh Musa (ul 24:1-4), dimana dalam perikop ini juga berbicara tentang pemberian surat cerai. Dalam perikop ini Yesus dengan jelas mengatakan bahwa"sejak semula tidaklah demikian". Mathew Henry mengatakan bahwa pemberian surat cerai dalam perjanjian Lama bukanlah sebuah indikasi bahwa hukum taurat memperbolehkan pasangan yang sudah menikah untuk bercerai, tetapi ini adalah merupakan sebuah gagasan perlindungan bagi kaum perempuan dalam arti bahwa pemberian surat cerai hanya memikirkan perlindungan dari aspek kemanusiaan belaka, bukan karena atas perintah dan persetujuan dari Tuhan. ${ }^{11}$

Nas ini sangat sering dikutip oleh para pendeta untuk menyampaikan Firman Tuhan dalam acara-acara pemberkatan nikah, dimana dalam hal ini ditekankan dan dipesankan kepada pasangan Kristen yang menikah agar tetap hidup dalam kesatuan karena mereka kini telah menjadi satu tubuh. Pernikahan telah dipakai oleh Tuhan Allah untuk menyatukan dua pribadi menjadi satu. Matius 19-20 merupakan penjelasan proses perjalanan Tuhan Yesus ke Yerusalem, orang-orang Farisi datang mengikuti Tuhan Yesus dan berusaha untuk mencobai Tuhan Yesus secara Khusus dalam hal pernikahan dan juga dalam proses perceraian. Dengan mengutip ulangan 24:1-4 mereka juga mengutif pandangan hillel : Apakah diperbolehkan menceraikan istri dengan setiap alasan?. ${ }^{12}$ Dalam klausa ini kita melihat sebuah tradisi yang berlaku bagi orang yahudi adalah bahwa kuasa untuk menceraikan istri ada pada suami. Situasi patrenial, dimana laki-laki berada pada posisi sebagai pemegang kendali dan kuasa bagi seorang perempuan, sehingga kecenderungan yang terjadi adalah bahwa yang memiliki hak adalah si laki-laki.

Kitab Matius yang sangat kental dengan pengaruh otoriter dari pemerintahan romawi yang sangat memperlihatkan perbedaan strata social yang sangat mencolok. Tuhan Yesus Kristus datang untuk menghapus segala dominasi satu kekuasaan yaitu pemerintahan romawi yang menghasilkan salah satunya adalah dominasi pria terhadap perempuan. ${ }^{13}$ Pemerintahan Romawi membuat aturan-aturan yang ketat yang harus dipenuhi oleh masyarakat yang berada dibawah kekuasaan mereka. Kaisar dianggap sebagai representasi kehadiran dewa ditengah-tengah masyarakat dan bahkan orang Kristen sendiri pun harus tunduk dan menyembah kaisar domitianus sebagai dewa dan sifat dari ketaatan ini adalah sesuatu yang sangat nutlak untuk dilakukan. Demikian juga dalam struktur social dan politik, dimana-mana ada kesenjangan social yang sangat tinggi. ${ }^{14}$ Dalam perjalanan Tuhan Yesus dari galilea, banyak orang berbondong-bondong mengikutiNya termasuk di

\footnotetext{
${ }^{10}$ Tim Penyusun, Tafsiran Alkitab Masa Kini Kejadian - Ester (Jakarta: YKBK, 2008).

${ }^{11}$ Matthew Henry, Tafsiran Injil Matius 1-14 (Surabaya: Momentum, 2007).

${ }^{12}$ Ross, Bercerai: Boleh Atau Tidak?: Tafsiran Terhadap Teks-Teks Perjanjian Baru.

${ }^{13}$ Sugirtharajah, A Post Colonial Commentary On The New Testament Writing.

${ }^{14}$ Stambaugh \& David Balch, Dunia Sosial Kekristenan Mula-Mula, n.d.
} 
dalamnya adalah orang-orang Farisi. Sehingga perikop matius 19:1-12 ini sangat kental isinya dengan perdebatan antara Tuhan Yesus dengan orang-orang Farisi yang berhubungan dengan topik perceraian. Orang-orang Farisi mempengaruhi Tuhan Yesus dengan cara mengutip apa yang dilakukan oleh Musa dalam Ulangan 24:1-4, yaitu dengan memberikan surat cerai pada masa kepemimpinannya. Leslie J.Hoppe berpendapat bahwa bagian di atas ini tidaklah hendak melegalkan perceraian. ${ }^{15}$ Sementara TAMKI menjelaskan bahwa hal ini bukanlah sebuah aturan legalisasi tentang perceraian. ${ }^{16}$ Saya melihat bahwa kedua tafsiran di atas dengan sangat tegas menolak bahwa hal itu bukanlah hendak mengatur hukum perceraian walaupun pada prakteknya bahwa bangsa Israel melakukannya. Tetapi sangat dengan tegas bukanlah untuk mengatur hukum perceraian. John Calvin mendukung penafsiran ini, bahwa kebiasaan bangsa Israel melakukan atau mempraktekkan perceraian bukan berdasarkan hukum Tuhan tetapi bisa saja oleh karena pengaruh-pengaruh bangsa sekitar mereka. ${ }^{17}$

Dalam Matius 5:31 Yesus juga Kembali mengutip perkataan musa, karena memang orang-orang farisi menggunakan ini sebagai dalih untuk mencecar Tuhan Yesus mengenai kebiasaan perceraian yang terjadi di dalam kehidupan bangsa Israel. Mathew Henri memberikan penafsiran, perceraian bukanlah merupakan sebuah hukum Tuhan dan pemberian surat cerai itu bukanlah untuk melegalkan tetapi hanya sebagai bentuk perlindungan terhadap hak azasi siperempuan dan pasangan lain dengan system pernikahan yang hanya berpusat kepada laki-laki. ${ }^{18}$ Seperti halnya J.J.De Heer dikeluarkannya surat cerai adalah untuk memproteksi seorang wanita dalam sebuah pernikahan serta memberikan status yang jelas terhadap si perempuan. ${ }^{19}$

Sesungguhnya perceraian bukanlah sebuah perintah Tuhan, walaupun dengan alasan bahwa seorang suami mendapati sesuatu yang senonoh dengan istrinya, oleh karena hal ini bukanlah sesuatu yang diperintahkan oleh Tuhan maka tidaklah wajib untuk dilakukan. Tetapi sebenarnya Tuhan Yesus secara berulang-ulang menyampaikan bahwa tidaklah boleh bercerai dan pernikahan harus dijaga sampai mati, dengan kata lain bahwa memang tidaklah boleh bercerai. Hal ini semakin dipertegas oleh leon morris, bahwa Tuhan Yesus mengajarkan sebuah persamaan harkat dan martabat antara laki-laki dan perempuan dan seharusnya menjadi sebuah prinsip keadilan, sehingga perempuan tidaklah menjadi orang yang selalu dirugikan dalam sebuah peristiwa perceraian. Perceraian bisa saja terjadi tetapi bukan itu yang diinginkan oleh Tuhan, karena dalam pemahaman kita, pernikahan itu adalah seumur hidup. ${ }^{20}$

${ }^{15}$ Craigh Blomberg, The New American Commentary: Mathew (USA: Broadman Press, 1992).

${ }^{16}$ Tim Penulis, Tafsiran Alkitab Perjanjian Lama (Yogyakarta: Kanisius, 2002).

${ }^{17}$ John Calvin, Harmony Of Law - Volume 3 (Grand Rapids MI: Christian Classic Ethereal Library, 1578).

73.

${ }^{18}$ Henry, Tafsiran Injil Matius 1-14. 201.

19 J. J. De Heer, Tafsiran Alkitab Injil Matius (Jakarta: BPK Gunung Mulia, 2003). 85.

${ }^{20}$ Leon Morris, The Gospel According to Mathew (Michigan: Grand Rapids, 1992). 
Dalam pandangan J.J.De Heer cerita tentang diperbolehkannya laki-laki menceraikan istrinya dengan alasan apa saja, dipengaruhi oleh pandangan para rabi di Israel yang cenderung setuju dengan pandangan Rabi Hillel, dimana suami dapat menceraikan istrinya apabila dia sudah tidak senang lagi. ${ }^{21}$ Dalam konteks matius 19:1-12, orang farisi berusaha untuk menjebak Tuhan Yesus dengan motivasi menjebak Tuhan Yesus agar memberikan jawaban yang sesuai dengan kebutuhan mereka. Tetapi pada ayat keempat, Tuhan Yesus justru memiliki kesempatan untuk memberikan penegasan tentang bagaiamana seharusnya kehidupan pernikahan Kristen, dan pada akhir ayat yang ke-6 dengan tegas Tuhan Yesus menyampaikan"....apa yang telah dipersatukan oleh Allah, tidak boleh diceraikan oleh Manusia", sehingga menurut penulis bahwa sebenarnya Tuhan Yesus secara tegas menolak baik ajaran Rabi Hillel maupun ajaran Rabi Syammai, karena keduannya sama-sama melegalkan perceraian walaupun dengan dasar dan alasan yang berbeda.

Blomberg memberikan penegasan tentang ayat 4-6, bahwa pernikahan Kristen sungguh tidak mengenal yang Namanya perceraian dengan alasan apapun, karena menurut bomberg pernikahan itu mengandung janji/covenant yang tidak boleh dilanggar karena mengakibat konsekwensi hukuman mati bagi yang melanggarnya. ${ }^{22}$

Seringkali yang me;ahirkan perdebatan adalah pada ayat 9, karena adanya kata "....kecuali karena zinah..." inilah yang menjadi ruang bagi Sebagian orang/ahli memberikan pendapatnya yang berbeda-beda. Tetapi menurut penulis perbedaan dalam injil Matius, Markus, Lukas dimana hanya matius yang mencantumkan kata “...kecuali karena zinah...." Dapat diterima oleh karena Matius menuliskan Injil untuk orang Yahudi, jadi praktek perceraian hanya terjadi bagi tradisi orang Yahudi. Menurut Barclay praktek perceraian hanya berlaku pada orang Yahudi.

Konteks Yesus berbicara pada perikop ini jelas adalah tentang perihal perceraian yang dipersoalkan oleh orang-orang Farisi, sehingga perikop Matius 19:1-12 merupakan sebuah kesatuan yang utuh dan tidak dapat dipisahkan. Kebiasaan orang romawi, dimana subordinasi laki-laki atas perempuan menjadi dasar Tuhan Yesus menyampaikan hal ini, dengan Tujuan bahwa Yesus ingin mengembalikan Konsep yang sesungguhnya tentang pernikahan Kristen yang sejak semula ditetapkan oleh Tuhan Yesus. Masalah teks menurut Ruth Schafer dan Freshia Aprilyn Ross, bahwa ada teks tertua, yaitu codex Sinaiticus, menggunakan kata $\alpha v \theta \rho \omega \pi \omega$ (seorang) dalam hal ini maksudnya adalah seorang suami. ${ }^{23}$

\section{KESIMPULAN}

Standard pernikahan yang diinginkan oleh Tuhan adalah, bahwa Dia menginginkan apa yang sudah dipersatukannya dalam ikatan pernikahan yang Kudus hendaknya dijaga dan dipelihara. Matius 19:6, harusnya menjadi dasar utama dari sebuah pernikahan, dan

\footnotetext{
${ }^{21}$ Heer, Tafsiran Alkitab Injil Matius.

22 Blomberg, The New American Commentary: Mathew.

${ }^{23}$ Ross, Bercerai: Boleh Atau Tidak?: Tafsiran Terhadap Teks-Teks Perjanjian Baru.
} 
setiap pasangan sebelum diberkati harusnya sungguh-sungguh menyadari kebenaran Firman Tuhan ini sehingga Ketika mereka menjalani bahtera Rumah Tangga yang tidak akan lepas dari persoalan maka pasangan itu sudah siap. Alkitab secara tegas menyatakan bahwa pernikahan itu adalah Kudus adanya dan tidak semestinya dikotori oleh keinginan dan kehendak manusia, walaupun sebenarnya kita tidak bisa mengabaikan begitu saja peristiwa perceraian yang bisa saja terjadi ditengah-tengah realitas kehidupan orang percaya. Tetapi sekali lagi realitas itu bukanlah dasar untuk melegalkan perceraian yang marak terjadi di tengah-tengah kehidupan orang percaya. Gereja harus sungguh-sungguh memberikan perhatian yang lebih serius lagi untuk mengajarkan tentang konsep pernikahan kekristenan yang sesungguhnya, apa yang harus diperhatikan, apa yang harus dihindari dan apa yang menjadi tanggungjawab masing-masing. Oleh karena pernikahan adalah sebuah ketetapan yang datang dari Tuhan maka pasangan-pasangan yang hendak menikah harus sungguh-sungguh menghargai pernikahan itu sendiri. Gereja tidak lagi boleh hanya sekedar memperhatikan masalah-masalah administrasi saja, tetapi juga harus benar-benar dengan pengajaran yang mendalam tentang arti dari pernikahan Kristen itu sendiri

\section{KEPUSTAKAAN}

Balch, Stambaugh \& David. Dunia Sosial Kekristenan Mula-Mula, n.d.

Blomberg, Craigh. The New American Commentary: Mathew. USA: Broadman Press, 1992.

Calvin, John. Harmony Of Law - Volume 3. Grand Rapids MI: Christian Classic Ethereal Library, 1578.

Carter, Warrant. Mathew and Empire: Initial Exploration, n.d.

Gundry, Mathew. A Commentary On His Handbook For A Mixed Church Under Persecution. Michigan Baker Akademik, 2010.

Harefa, Otieli. "Keluarga Sebagai Pusat Pembentukan Rohani Anak." Real Didache 1, no. 1 (2016): 1-22.

Heer, J. J. De. Tafsiran Alkitab Injil Matius. Jakarta: BPK Gunung Mulia, 2003.

Henry, Matthew. Tafsiran Injil Matius 1-14. Surabaya: Momentum, 2007.

Morris, Leon. The Gospel According to Mathew. Michigan: Grand Rapids, 1992.

Newman, BGM Morph + Barclay -. "Bible Work 6," n.d.

Penulis, Tim. Tafsiran Alkitab Perjanjian Lama. Yogyakarta: Kanisius, 2002.

Penyusun, Tim. Tafsiran Alkitab Masa Kini Kejadian - Ester. Jakarta: YKBK, 2008.

Ross, Schafer dan Freshia Aprily. Bercerai: Boleh Atau Tidak?: Tafsiran Terhadap TeksTeks Perjanjian Baru. Jakarta: BPK Gunung Mulia, 2017.

Simanjuntak, Fredy. "Problematika Disorganisasi Dan Disharmonisasi Keluarga." In Keluarga Yang Misioner, 2018.

Sugirtharajah. A Post Colonial Commentary On The New Testament Writing, n.d.

Widjaja, Fransiskus Irwan. "Manajemen Konflik Keluarga." In Keluarga Yang Misioner, 103-111, 2018. 